\title{
IMPACT OF INTEGRATION PROCESSES IN FORMATION BUSINESS-MODELS OF AGRI-INDUSTRIAL ENTERPRISE
}

\author{
Olena Pimenova \\ Taras Shevchenko National University of Kyiv \\ Serhii Pimenov \\ Ukrainian Logistic Company \\ Taras Shevchenko National University of Kyiv
}

\begin{abstract}
The essence and effectiveness of integration processes in the agrarian sector of Ukraine is studied. The influence of integration processes on the formation of business-models of agro-industrial enterprises is analyzed. The world experience of agricultural cooperation is examined. For the results of the study is found that the effective form of integration that ensures competitiveness peasants and farmers, promotes their business efficiency by servicing its members in the field of processing, delivery, sales, marketing, consulting and even the production of major agricultural products, on the one hand and on the other hand provides a rural population with goods and services of daily use is agricultural service cooperatives.
\end{abstract}

Key words: agrarian sector integration processes, agri-industrial enterprises, business-model, agrihoding, agricultural service cooperative, farms

\section{INTRODUCTION}

Modern trends in National Economy clearly demonstrate the need for a deep understanding of conceptual problems of integration process in agrarian sector and their institutional support. The strategic importance of activating their operation in conditions on the one hand multifunctionality of agriculture and on the other hand of weakness, inversion and deformability of agrarian relations due to the emergence of new opportunities in the implementation of restructuring of agrarian sector and creation of an effective competitive environment. 
We believe that integration processes in agrarian sector of Ukraine, which contribute to the development of national economies, the creation of added value in the territory of our country, are very important for modern agrarian relation in Ukraine.

The theoretical bases of competitiveness were formed in the works of such renowned foreign scholars as Krugman, Porter and Varnaliy. Practical aspects and problems of relevance of improving the competitiveness of agricultural enterprises widely covered in the works of Ukrainian and foreign scientists such as: Fylyuk, Bayura, Wasilewski, Geyets, Zabolotnyy, Zvirbule-Berzin, Kovalenko, Moldavan, Paskhaver, Sabluk and others. The issue of institutional maintenance of transformation of agrarian sector in changing global economic fundamental tenets of science covered in the works of Bazilevich, Lopatynsky, Malik, Shpykulyak, Luzan, Chorna and others. However, despite the size and significance of scientific research, not illuminated remain above all, aspects related to the study of effectiveness of integration processes in agrarian sector of Ukraine.

The aim is to study the nature and effectiveness of integration processes in agrarian sector of Ukraine and the impact of integration processes on the formation of business- models of agro-industrial enterprises.

\section{LITERATURE REVIEW}

In Ukraine scientific literature, in the study of integration processes in agriculture, the focus is on the effectiveness of large-scale economic activities in Ukraine, that is, the economic component of agriculture, while the small and medium-sized farms of Ukraine, which produce about $50 \%$ of the main agricultural products, and combine economic, ecologic and social components of agriculture remain poorly researched. Such studies are vividly illustrated in the writings of Kovalenko, Moldavan, Fyliuk, Chorna and others. At the same time, aspects of the analysis of the experience of forming effective business models of agricultural enterprises under the influence of integration processes in the developed countries, in particular Poland, are still not sufficiently investigated and still in need of in-depth study. In this context, the works of Western scholars such as Andra Zvirbule-Berzina, Wasilewski, Wasilewska, Bezat, Zabolotnyy are gaining special significance for Ukraine.

\section{METHODS OF THE STUDY}

The methodological and theoretical basis of the study is the scientific works of Ukrainian and foreign scholars on issues of integration processes in agrarian sector. To achieve this goal we used the system of general and special methods of study. 
The paper uses the techniques of abstract logical method, namely, induction and deduction, analogy. Moreover, in the work were used the statistical methods of data processing, monographic analysis of literary sources (theoretical aspects of business modeling), the method of analysis and synthesis, comparative analysis. To assess the effectiveness of integration processes were used the methods of statistical and tabular display.

\section{RESULTS}

Agriculture of Ukraine is the most dynamically developing branch of economy of Ukraine, which provides $11 \%$ of total GDP. Thus, according to the Ministry of Ukrainian Agrarian Policy the yield of grain crops in Ukraine in 2016/2017 marketing year (MY) is expected to reach 63.45 mil tons. In particular, the forecast of wheat harvest is 26 million tons, barley is $9.6 \mathrm{mln}$ tons, corn is $25.5 \mathrm{mln}$ tons, rye is 370 thousand tons, oats are 525 ths. tons, rice is 65 ths tons and other grains are 1.39 mln tons. The demand of internal market for grain in current marketing year is estimated at $24.533 \mathrm{mln}$ tons. Where for food we need only $5.95 \mathrm{mln}$ tons. In particular the forecast of internal demand for wheat is $10.53 \mathrm{mln}$ tons, barley is $4.034 \mathrm{mln}$ tons, corn is $8.18 \mathrm{mln}$ tons, rye is 386 thousand tons, oats is 513 ths. tons, rice is 141 ths. tons and other grains are $747 \mathrm{mln}$ tons.

Thus, in case of formation the sufficient transition residues for support of food security (5.6 million tons), rational grain export from Ukraine in 2016/2017 marketing year is estimated at $41.02 \mathrm{mln}$ tons, of which the wheat should be 16.6 million tons, barley is 5,61 mln tons, corn is $18.00 \mathrm{mln}$ tons and other grains are 804 thousand tons.

As you can see the agriculture of Ukraine is also export-oriented branch of national economy, which provides about $40 \%$ of foreign exchange earnings from exports of goods. Thus, in January-July 2016 Ukraine exported cereals at 3 bln dollars. According to the State Statistics Service of Ukraine an export of agricultural products from Ukraine in the first seven months of 2016 amounted to $7.8 \mathrm{bln}$ dollars, the bulk of which were products of plant origin for $3.8 \mathrm{bln}$ dollars. Almost $29 \%$ of agricultural external supplies are fats and oils of animal and vegetable products at $2.3 \mathrm{bln}$. Exports of live animals and animal products reached to $0.4 \mathrm{bln}$ dollars and ready food products to 1.3 bln dollars.

There are such basic forms of economy in agriculture of Ukraine: farms, peasant economies and agricultural enterprises (mainly in the form of integrated structures of agri-industrial complex - agriholdings). These agricultural producers produce basic agricultural products in the following proportions: peasant economies $-43.01 \%$, farms $-8.68 \%$, agricultural enterprises $-48.31 \%$, (agriholdings) $-44.9 \%$ (table. 1 ). 
TABLE 1. Gross agricultural production by major producers in 2016

\begin{tabular}{|l|c|c|}
\hline Producer & GAP, mln UAH & Share (\%) \\
\hline Agricultural enterprises & 123017.6 & 48.31 \\
\hline Farms & 22101.4 & 8.68 \\
\hline Peasants & 109521.5 & 43.01 \\
\hline
\end{tabular}

Source: Compiled by the author according to: Agriculture of Ukraine 2016, State Statistics Service of Ukraine, Statistical Bulletin, State Statistics 2015 i 2017.

As you can see, the main agricultural producers in Ukraine are peasant economies and agricultural enterprises, mostly in the form of agriholdings. Moreover, the peasant economies produce the bulk consuming food products, while agriholdings activities focused on growing high margin export of agricultural products (table 2, 3, 4).

TABLE 2. Production of major crops by category of producers for 2000-2016 [ths. tons]

\begin{tabular}{|c|c|c|c|c|c|c|c|c|c|}
\hline \begin{tabular}{|l|} 
Peasant \\
economies
\end{tabular} & 2000 & 2005 & 2010 & 2011 & 2012 & 2013 & 2014 & 2015 & 2016 \\
\hline $\begin{array}{l}\text { Grains and } \\
\text { legumes }\end{array}$ & 4494.8 & 9225.1 & 9491.6 & 12527.5 & 10141.2 & 13392.3 & 13956.7 & 13619.2 & 13725.4 \\
\hline Sugar beet & 1604.7 & 3322.4 & 1085.8 & 1595.1 & 1601.2 & 1688.6 & 1134.7 & 777.0 & 1562.3 \\
\hline Sunflower & 431.7 & 996.2 & 1185.9 & 1381.7 & 1256.0 & 1604.7 & 1452.1 & 1631.9 & 1782.5 \\
\hline Potato & 19561.4 & 19222.7 & 18222.3 & 23495.9 & 22493.2 & 21599.2 & 22934.5 & 20383.3 & 22420.9 \\
\hline Vegetables & 0.0 & 4.3 & 7157.8 & 2.4 & 8582.8 & 8719.9 & 8297.2 & 7932.3 & 8291.0 \\
\hline $\begin{array}{l}\text { Fruits and } \\
\text { berries }\end{array}$ & 1 & 8 & .7 & 7 & 1639.5 & .1 & .1 & .1 & 2 \\
\hline \multicolumn{10}{|c|}{ Agricultural enterprises } \\
\hline $\begin{array}{l}\text { Grains and } \\
\text { legumes }\end{array}$ & 9964.2 & 28790.4 & 29779.3 & 44219.3 & 36075.0 & 49659.0 & 49902.6 & 46506.6 & 55725.4 \\
\hline Sugar beet & 11594.1 & 12145.4 & 12663.4 & 17145.4 & 16837.7 & 9100.8 & 14599.4 & 9553.8 & 56282.5 \\
\hline \begin{tabular}{|l|} 
Sunflower \\
\end{tabular} & 3025.7 & 37099 & 5585.6 & \begin{tabular}{|l|}
7288.8 \\
\end{tabular} & \begin{tabular}{|l|}
7131.1 \\
\end{tabular} & 9445.8 & 8681.7 & 9549.2 & 9634.1 \\
\hline Potato & 276.7 & 780.7 & 964.6 & 1540.5 & 1433.9 & 1158.7 & 1340.3 & 456.0 & 521.0 \\
\hline Vegetables & 986.3 & 780.7 & 964.6 & 1540.5 & 1433.9 & 1158.7 & 1340.3 & 1281.7 & 1159.8 \\
\hline $\begin{array}{l}\text { Fruits and } \\
\text { berries }\end{array}$ & 264.1 & 200.1 & 286.8 & 299.8 & 369.0 & 444.2 & 332.0 & 411.7 & 359.8 \\
\hline
\end{tabular}

Source: Compiled by the author according to: Agriculture of Ukraine 2016, State Statistics Service of Ukraine, Statistical Bulletin, State Statistics 2015 i 2017.

Analysis of the data from table 2 and 3 suggests that the largest number of certain types of animal products like meat, milk and labor-intensive kinds of crops (potatoes, vegetables, fruits and berries) are produced in peasant economies.

Tables 2-4 show that agriholdings grow mainly oil and fat high margin export agricultural products and operate with efficiency not lower than $50-55 \%$ in crop 
production, while peasant economies grow labor-intensive basic food and agricultural products with low labor income and profits. As we can see that the production of the first group is directed primarily to meet the internal demand, so the second one - mainly for export.

TABLE 3. Production of major livestock by category of producers for $2000-2016$ [ths. tons]

\begin{tabular}{|l|c|c|c|c|c|c|c|c|c|}
\hline Detailed & 2000 & 2005 & 2010 & 2011 & 2012 & 2013 & 2014 & 2015 & 2016 \\
\hline Meat & 1224.7 & 10089.0 & 924.6 & 928.5 & 938.4 & 948.1 & 907.8 & 859.2 & 920.1 \\
\hline Milk & 8989.2 & 11131.9 & 9031.9 & 8840.1 & 8842.3 & 8905.7 & 8485.3 & 7946.2 & 7942.2 \\
\hline $\begin{array}{l}\text { Eggs, mln } \\
\text { pieces }\end{array}$ & 5831.3 & 6587.8 & 6802.7 & 6951.6 & 7133.0 & 7380.6 & 7051.1 & 7020.7 & 7011.6 \\
\hline Wool, tons & 2089 & 2503 & 3482 & 3230 & 3168 & 3050 & 2223 & 1956 & 1948 \\
\hline Honey, tons & 48875 & 69001 & 69253 & 68815 & 68717 & 72390 & 65539 & 62697 & 64526 \\
\hline & & \multicolumn{7}{|c|}{ Agricultural enterprises } & \\
\hline Meat & 438.1 & 588.1 & 1134.4 & 1215.3 & 1271.2 & 1441.3 & 1451.8 & 1463.4 & 1465.4 \\
\hline Milk & 3668.7 & 2582.5 & 2216.6 & 2245.9 & 2535.3 & 2582.5 & 2647.5 & 2669.2 & 2652.1 \\
\hline $\begin{array}{l}\text { Eggs, mln } \\
\text { pieces }\end{array}$ & 2977.3 & 6458.1 & 10249.6 & 11738.2 & 11977.4 & 12234.2 & 12536.2 & 9762.2 & 9658.5 \\
\hline Wool, tons & 1311 & 692 & 710 & 647 & 556 & 470 & 379 & 314 & 309 \\
\hline Honey, tons & 3564 & 2461 & 1620 & 1496 & 1417 & 1323 & 982 & 918 & 967 \\
\hline
\end{tabular}

Source: Compiled by the author according to: Compiled by the author according to: Agriculture of Ukraine 2016, State Statistics Service of Ukraine, Statistical Bulletin, State Statistics 2015 i 2017.

TABLE 4. Level of profitability of the production of basic agricultural products in Ukraine for the period of 2012-2015 [\%]

\begin{tabular}{|l|c|c|c|c|}
\hline Plant products & 2012 & 2013 & 2014 & 2015 \\
\hline Grains and legumes & 15.8 & 2.4 & 25.7 & 42.6 \\
\hline Sunflower seeds & 44.9 & 28.2 & 36.7 & 78.4 \\
\hline Sugar beet & 15.9 & 3.1 & 17.8 & 27.7 \\
\hline Vegetables & -0.6 & 7.5 & 14.5 & 32.0 \\
\hline Potato & -17.4 & 22.4 & 9.9 & 24.6 \\
\hline Fruits and berries & 9.6 & 127.5 & 65.8 & 58.3 \\
\hline Grape & 71.5 & 99.0 & 57.5 & 92.9 \\
\hline Milk & 1.8 & 13.1 & 11.1 & 12.7 \\
\hline Cattle and meat & -28.3 & -41.3 & -34.5 & -16.9 \\
\hline Pig meat & 1.8 & 0.2 & 5.6 & 12.6 \\
\hline Sheep and goats for meat & -32.8 & -36.2 & -43.0 & -26.6 \\
\hline Poultry meat & -2.4 & -5.9 & -12.6 & -5.4 \\
\hline Eggs & 52.6 & 47.6 & 58.8 & 60.9 \\
\hline
\end{tabular}

Source: Compiled by the author according to: Compiled by the author according to: Agriculture of Ukraine 2016, State Statistics Service of Ukraine, Statistical Bulletin, State Statistics 2015. 
The analysis of statistical data (tables 1-4) shows that Ukraine is the world leader in crop production and export of cereals, pulses, oilseeds, sunflower and soybean oil. However, the vast majority of production is exported as raw materials and not processed in Ukraine. Thus, exporting raw materials Ukraine does not use the possibility of creating added value in its territory without thereby creating jobs in manufacturing.

On the other hand the main food products, which produced in peasant economies been realized by small quantities as raw materials at extremely low prices to intermediaries or directly to processors of agricultural products on internal market. Among the main factors that contribute to such a scheme of work, in our opinion, can be identified the fragmentation of small farms and peasant economies and therefore inability to compete with larger forms at aggressive market environment. Thus, among the most promising areas that will improve the efficiency of agricultural production, including processing industry for national economy, in our opinion, can distinguish the development of integration processes in agrarian sector of Ukraine.

Integration in the narrow sense is the process of combining some elements into one in order to get the desired result. In the broad sense integration means organizational combination of technologically interconnected heterogeneous activities for the production of final product and bring it to the consumer to obtain an intended result. In agriculture the integration provides the development of industrial and economic links between agricultural enterprises that focus on a combination of land, financial, human and other resources for production and sale of the final product [Chorna 2015, p. 380]. We believe that the integration process should contribute to:

- combining the interests of all participants who combined for the purpose of manufacturing, processing and sales,

- the organization of the whole process of production, procurement, processing products,

- effective management of the processes of production, processing and marketing,

- efficient use of resources of agricultural enterprises and other stakeholders integration,

- use the modern technologies, the latest technology and research in the production and processing of agricultural products.

In modern conditions of economic relations could be distinguished such types of integration in agriculture:

1. The horizontal integration is a form of association of agricultural enterprises that produce similar products. Most often occurs in an environment where one firm takes under control or absorb another firm that operates in the same branch and the same chain of production like the same firm that absorbing another. 
2. Vertical integration is a form of association of agricultural enterprises, as well as areas of support activities that ensure the unity and continuity of the reproduction and technological processes and use of production resources. Provides the process of merger the stages of production, thereby reducing of transaction costs and optimization of the production.

3. Conglomerate integration is a form of association of agricultural enterprises that produce completely different unrelated products technologically interconnected.

4. Local integration is a form of association of agricultural enterprises that operate in local markets.

5. Regional integration is a form of association of agricultural enterprises to promote strong economic ties and creating a single economic complex in the regional scale.

6. Transnational integration is a form of association of agricultural enterprises of different countries, regions under globalization.

In agriculture of Ukraine dominates mainly horizontal and vertical integration of agricultural enterprises (table 5). The horizontal and vertical integration of enterprises could be based on principles both as cooperative as well as non-cooperative:

TABLE 5. Forms of dimensional integration

\begin{tabular}{|l|l|l|}
\hline $\begin{array}{l}\text { Integration } \\
\text { principles }\end{array}$ & Vertical integration & Horizontal integration \\
\hline Non-cooperative & $\begin{array}{l}\text { Agricultural enterprises integrate } \\
\text { vertically in order to strengthen } \\
\text { control over the production, pro- } \\
\text { cessing and sales. }\end{array}$ & $\begin{array}{l}\text { Agricultural enterprises integrate } \\
\text { horizontally on the principles of } \\
\text { concentration, consolidation and } \\
\text { specialization. }\end{array}$ \\
\hline Cooperative & $\begin{array}{l}\text { Peasants, farmers and enterprises } \\
\text { of agrarian sector integrate in or- } \\
\text { der to implement common goals } \\
\text { united on the principles of vertical } \\
\text { integration. }\end{array}$ & $\begin{array}{l}\text { Peasants, farmers and enterprises } \\
\text { to agrarian sector integrate in order } \\
\text { on principles of horizontal integra- } \\
\text { tion. }\end{array}$ \\
\hline
\end{tabular}

Source: Compiled by the author according to: Compiled by the author according to: Agriculture of Ukraine 2016, State Statistics Service of Ukraine, Statistical Bulletin, State Statistics 2015.

In agriculture of Ukraine presented mainly non-cooperative horizontal integration and partially cooperative vertical and horizontal integration. Let analyze the data in table 6.

As you can see, among modern forms of economies operating in agrarian sector of Ukraine presented such business-models of agri-industrial enterprises as agriholdings in the form of private agricultural enterprises and agricultural cooperatives (mainly servicing and partially production). Agriholdings are the large capitalist agro-business enterprises that use tens of thousands of hectares of 
TABLE 6. Forms of economy in agrarian sector of Ukraine for $2014-2016$ [\%]

\begin{tabular}{|l|c|c|c|c|c|}
\hline Form of economy & 2012 & 2013 & 2014 & 2015 & 2016 \\
\hline Agriholdings & 16.7 & 16.8 & 16.8 & 17.0 & 17.0 \\
\hline Private agricultural enterprises & 8.5 & 8.3 & 8.2 & 8.0 & 8.0 \\
\hline Agricultural cooperatives & 1.7 & 1.6 & 1.4 & 1.3 & 1.2 \\
\hline Farms & 68.9 & 69.7 & 71.6 & 71.2 & 71.3 \\
\hline Public enterprises & 0.6 & 0.6 & 0.5 & 0.5 & 0.5 \\
\hline Other enterprises & 3.6 & 3.0 & 1.5 & 2.0 & 2.0 \\
\hline Total & 100 & 100 & 100 & 100 & 100 \\
\hline
\end{tabular}

Source: Compiled by the author according to: Compiled by the author according to: Agriculture of Ukraine 2016, State Statistics Service of Ukraine, Statistical Bulletin, State Statistics 2015 i 2017.

farmland for growing the most profitable and technologically mechanized crops (sunflower, rape, spiked cereals, maize) with the use of chemical fertilizers, pesticides, herbicides and other remedies plant to produce high yields. Agriholdings belonging to regional integrated non-cooperative horizontal structures in production sphere. Nowadays agriholdings concentrate about 5 million hectares or nearly $15 \%$ of arable land in Ukraine. The activity of agriholdings is regulated by the law "About Business Associations" in Ukraine. Differences between agriholding and agricultural service cooperative are presented in Table 8.

Agricultural cooperatives are a form of regional cooperative vertical integration in agrarian sector. In Ukraine an activity of agricultural cooperative is regulated by such legislation: Law of Ukraine "About Agricultural Cooperation" and "About Cooperation", Land Code, Commercial Code. Agricultural cooperatives are divided on production and service. Production cooperatives hardly represented in Ukraine, while their development is of particular relevance for peasants, which produce the vast number of agricultural products, as was shown above $54.5 \%$ of gross agricultural production (tabel 8).

TABLE 7. Main advantages of accession peasants in agricultural cooperative

\begin{tabular}{|l|l|}
\hline $\begin{array}{l}\text { Type of agricultural } \\
\text { cooperation }\end{array}$ & Activity \\
\hline purchase & $\begin{array}{l}\text { wholesale purchases of means of production for the cooperative's } \\
\text { members that profitable then in retail }\end{array}$ \\
\hline credit & the possibility of cheap credit \\
\hline sales & realization of bulk goods on more favorable conditions \\
\hline processing & joint processing, drying products, etc. \\
\hline machine & $\begin{array}{l}\text { purchasing and sharing of necessary agricultural machinery for } \\
\text { cooperative members }\end{array}$ \\
\hline
\end{tabular}

Source: Compiled by the author according to: CHAYANOV A.V. 1991: Main ideas and forms of organization of agricultural cooperatives, A. Nikonov eds., Nauka. 
According to the Law of Ukraine "About Agricultural Cooperation" production cooperative is a voluntary association of citizens on the basis of membership for joint production or other economic activity, based on their personal labor participation and association property shares, participation in enterprise management and distribution income between the members according to their participation in its activities.

Service cooperatives according to the Law of Ukraine "About Agricultural Cooperation" [The law of Ukraine...] are cooperatives which are created to provide a range of services related to maintenance and other agricultural production, namely: processing, realization of crop production, livestock, forestry and fisheries.

To service cooperatives belong:

- processing cooperatives engaged in processing of agricultural products (bakery, pasta, vegetables, fruit, meat, dairy and fish products and semi-finished products from flax, hemp, timber and forest technology, etc.),

- harvesting \& sales cooperatives engaged in harvesting, storage and sale of products, provide marketing services etc.,

- procurement cooperatives created for the purchase and supply of means of production, material and technical resources required for the production of agricultural products and processed products; production of raw materials and supply it to agricultural producers,

- service cooperatives engaged in technology, transportation, reclamation, maintenance, construction, environmental restoration works, make veterinary care of animals and breeding work involved telephone, gasification, electrification in rural areas, provide medical, household, spa, scientific advisory services, administration of accounting, auditing and more.

World practice of agriculture shows that agricultural cooperative is an important organizational foundation for small and medium-sized forms. European and American farmers realize the bulk of agricultural production through cooperatives. Thus, in France through cooperatives, farmers sold up to $70 \%$ of grain. Three steppe cooperative of Canada (Saskatchewan Grain Pool, Wheat Alberta Cooperative and Manitoba Elevator Cooperative, which unite a quarter of farmers of Canada) realized their bulk grains and oilseeds in 20 different countries. These cooperatives employed more than 5,000 professionals and skilled workers. The members of these cooperatives are about 100.000 farmers. Through cooperatives sold $60 \%$ of grains and oilseeds. For export operations in three cooperatives was established a pooling cooperative XCAN Grain Pool, which on behalf of member-farmers exported more than $2.5 \mathrm{mln}$ tons of grain, oilseeds and special crops [Moldavan 2010; Wasilewski, Wasilewska, Bezat 2010; Zabolotnyy 2011]. 
Agricultural cooperation is the key to successful development as farmers as well agriculture in general. One of the features of an agricultural service cooperative is that its members as acting as a co-owner of the enterprise (cooperative) as well his customers.

The benefits of agricultural cooperative that might be interesting for farmers, in our opinion, include:

- owned by member-farmers who joined, or joined to the cooperative,

- managed by members on democratic principles, the principle of "one member of the cooperative is one vote",

- does not aim to make a profit, its aim is to increase the income of members,

- provides for mandatory labor participation of each member,

- provides its members with only those services that are necessary for their effective work,

- provides an ability to make a profit not only from producing their own products, but also on: service delivery, collection, storage, processing, transportation, wholesale, etc.,

- helps to enter new markets including international,

- by providing a large volume of business transactions cooperative compete with large firms-intermediaries,

- helps farmers to adapt to market requirements, customer needs, etc.

Joint sales of products enable farmers to sell large quantities of the most important types of food: potatoes, carrots, beets and other vegetables, fruits, honey and more. Cooperative as a large agricultural enterprise, which can successfully collaborate with processors, wholesale buyers and other market operators. Through service cooperatives farmers can buy the newest agricultural machinery (tractors, seeders, combines, etc.), which will facilitate the most effective process of agricultural production. But the most important is that members of an agricultural cooperative self manage its economy and through cooperative perform those activities that will contribute to a more efficient production process. That agricultural service cooperative is an organization of economic security and mutual agricultural producers.

Agricultural service cooperative unlike agriholdings performs the most important social function of agriculture: creates jobs in rural areas, provides guarantees jobs, improves the social protection of rural population and improves living standards in rural areas etc.

As we can see from table 8 agricultural cooperative has some social features that are missing in agriholding in which property relations and labor relations are delineated. Thus, in the current economic conditions, on our opinion, there is a need of theoretical justification of the development of a system of agricultural cooperation that is very important for peasants, which produce the vast number of agricultural products. The development of agricultural cooperation primarily depends on institu- 
TABLE 8. Differences between agriholding and agricultural service cooperative

\begin{tabular}{|c|c|c|}
\hline Indicators & Agriholding & Agricultural service cooperative \\
\hline Condition of exist & own or loan capital & $\begin{array}{l}\text { capital in the form of introductory } \\
\text { and shares, debt capital and } \\
\text { personal labor participation }\end{array}$ \\
\hline Management & $\begin{array}{l}\text { management of an enterprise } \\
\text { performs its bodies, the } \\
\text { composition and election } \\
\text { procedure is performed according } \\
\text { to the type of partnership. In } \\
\text { stock companies the development } \\
\text { and management of the } \\
\text { enterprise provides the person } \\
\text { who has the largest number or } \\
\text { controlling stake }\end{array}$ & $\begin{array}{l}\text { cooperative control based on } \\
\text { self-publicity, participation } \\
\text { of its members in matters of } \\
\text { the cooperative. Cooperative } \\
\text { is managed by its members } \\
\text { on democratic principles, the } \\
\text { principle of "one member of an } \\
\text { cooperative is one vote" }\end{array}$ \\
\hline Membership & a limited number of shareholders & $\begin{array}{l}\text { membership is open and } \\
\text { voluntary, but members of a } \\
\text { cooperative must be agricultural } \\
\text { producers, who are at the same } \\
\text { time: and customers and owners } \\
\end{array}$ \\
\hline Goal of production & profit on capital & increasing income of its members \\
\hline Property relations & $\begin{array}{l}\text { stock ownership is the owner of } \\
\text { the property, which transferred } \\
\text { to it by participants in a property, } \\
\text { as a contribution to share capital; } \\
\text { products; received incomes from } \\
\text { sales }\end{array}$ & $\begin{array}{l}\text { collective ownership is the owner } \\
\text { of the property and the farm land; } \\
\text { products; received incomes from } \\
\text { sales }\end{array}$ \\
\hline Entity & $\begin{array}{l}\text { owner of capital and means of } \\
\text { production }\end{array}$ & staff members of the cooperative \\
\hline Work & not obligatory labor participation & $\begin{array}{l}\text { mandatory labor participation of } \\
\text { all members }\end{array}$ \\
\hline $\begin{array}{l}\text { Investment in rural } \\
\text { development }\end{array}$ & $\begin{array}{l}\text { not interested because it reduces } \\
\text { profit of an association }\end{array}$ & $\begin{array}{l}\text { interested as members of a } \\
\text { cooperative are habitants of a } \\
\text { village }\end{array}$ \\
\hline Attitude to market & sells its products on the market & $\begin{array}{l}\text { sells some of its products on the } \\
\text { market }\end{array}$ \\
\hline $\begin{array}{l}\text { Mobility as to } \\
\text { changes the } \\
\text { economic activity }\end{array}$ & $\begin{array}{l}\text { easy to change the type of } \\
\text { production and industry }\end{array}$ & $\begin{array}{l}\text { work on the ground and only in } \\
\text { agriculture }\end{array}$ \\
\hline
\end{tabular}

Source: Own elaboration.

tional support, namely: state support, which is mainly manifested in the creation of an appropriate legislative framework conducive to the development of agricultural cooperatives in Ukraine, as well as the financial support of the establishment of material-technical base for cooperatives. 


\section{CONCLUSIONS}

The results of the analysis of the nature and efficiency of integration processes in agrarian sector of Ukraine, as well as the impact of integration processes on the formation of business-models of agri-industrial enterprises can conclude that agricultural cooperative as a modern business-model of agri-industrial enterprise, on the one hand is rational socio-ecologo-economic form of economy and on the other hand is an effective form of regional cooperative vertical integration in agrarian sector as providing necessary services to its members contributes to the competitiveness and effective management as well as provides rural employment, self-employment of farmers while maintaining their economic independence in collaboration with the cooperative.

The analysis of foreign experience of farming confirmed that strengthen the competitiveness of national agricultural products in the context of globalization can be based on the development of agricultural service cooperatives. In particular, it is proved that the rational activity in agriculture provide only such form of economies which take into account the socioeconomic and geophysical specifics of agriculture, especially agricultural labor and management methods. The most common among these forms are peasant economies and farms which are integrated into agricultural cooperatives.

\section{References}

BAZYLEVYCH, V. D., BAZYLEVYCH, K. S. 2008: Rynkova ekonomika: osnovni ponyattya i kategoriji, Market economy: basic concepts and categories, Znannya.

CHORNA N. 2015: Development of integration processes as a prerequisite condition for increasing the efficiency of agribusiness, www.nbuv.gov.ua/old_jrn/Soc_Gum/ Ecan/2011_9_1/pdf/chorna.pdf

CHAYANOV A.V. 1991: Main ideas and forms of organization of agricultural cooperatives, A. Nikonov eds., Nauka.

FYLYUK G. M., PIMENOVA O. V. 2014: State Support of Agriculture: the Analysis of an Experience of Germany. Zarządzanie Finansami i Rachunkowość/Szkoła Główna Gospodarstwa Wiejskiego w Warszawie, 4, p. 19-30.

KOVALENKO G. 2012: State and prospects of integration Processes in agriculture in the sphere of public production, [Electronic resource]: http://econjournal.vsau.org/files/ pdfa/728.pdf

MOLDAVAN L. V. 2012: Socio-economic nature of agricultural enterprises. the monograph, Innovative transformation of the agricultural sector, Institute of Economics and Forecasting.p. 235-250. 
PIMENOVA O.V. 2013: Institutional maintenance of forms of economy in the system of agrarian relationship. Taras Shevchenko National University of Kyiv, Kyiv.

WASILEWSKI M., WASILEWSKA A., BEZAT A. 2010: Innowacyjnosìcì przedsiębiorstw przetwoìrstwa rolno-spożywczego: stan wiedzy i kierunki dalszych badanì. Zeszyty Naukowe Szkoły Głol̀wnej Gospodarstwa Wiejskiego w Warszawie, Ekonomika i Organizacja Gospodarki Żywnościowej, 8, p. 103-114.

ZABOLOTNYY S. 2011: Pomiar wpływu strategii płynnosìci finansowej na efektywnosìcci spoiłek giełdowych z sektora agrobiznesu, Zeszyty Naukowe Uniwersytetu Szczecinìskiego, nr 639, 37, p. 171-180.

ZVIRBULE-BERZINA A., 2011: The role of enterprise integration in agriculture entrepreneurship, papers.ssrn.com/sol3/papers.cfm?abstract_id=2232640

Agriculture of Ukraine, State Statistics Service of Ukraine, Statistical Bulletin.

Ministry of Agrarian Policy and Food of Ukraine. Electronic data, access: http://minagro. gov.ua

The law of Ukraine "About Agricultural Cooperation, access: zakon2.rada.gov.ua/laws/ show/469/97-\%D0\%B2\%D1\%80 